\title{
Attachment of a Pseudomonas-like bacterium and Bacillus coagulans to solid surfaces and adsorption of their S-layer proteins
}

\author{
Kay Bidle, ${ }^{1}$ H. Hollis Wickman, ${ }^{2} \uparrow$ and Madilyn Fletcher ${ }^{1 *}$ \\ ${ }^{1}$ Center of Marine Biotechnology, Maryland Biotechnology Institute, University of Maryland System, \\ 600 East Lombard Street, Baltimore, Maryland 21202, USA \\ ${ }^{2}$ Department of Chemistry, Oregon State University, Corvallis, Oregon 97331, USA
}

(Received 26 October 1992; revised 17 February 1993; accepted 16 March 1993)

\begin{abstract}
The role of S-layer proteins in bacterial adhesion to solid surfaces was investigated by determining whether there was a relationship between the adsorption of S-layer protein and the attachment of the source bacteria to a series of substrata exhibiting a range of water-wettabilities. Polystyrene substrata, prepared by treatment with $\mathrm{H}_{2} \mathrm{SO}_{4}$, provided advancing water contact angles ranging from $76^{\circ}$ to $46^{\circ}$. The test bacteria were a Pseudomonas-like strain, designated EU2, and the thermophilic bacterium Bacillus coagulans. In two out of four cases, S-layer adsorption paralleled cell attachment. Numbers of attached EU2 and amount of S-layer adsorption in phosphate buffer both increased with increasing substratum hydrophobicity. Numbers of attached $B$. coagulans and S-layer adsorption in distilled deionized water both decreased with increasing substratum hydrophobicity. The inconsistencies in attachment and S-layer adsorption observed in the remaining experiments were possibly due to the fact that S-layer proteins were free to adsorb by both inner and outer faces, whereas S-layer on the cell could adsorb only by the outer face. The results indicated that $\mathrm{S}$-layers may play a role in bacterial adhesion to surfaces, but that the adhesiveness of S-layers depends upon their specific chemistry and environmental conditions such as medium composition and temperature.
\end{abstract}

\section{Introduction}

A wide variety of eubacteria and archaebacteria have S-layer proteins, which are composed of subunits that assemble to form tetragonal, hexagonal or oblique crystalline lattices that completely cover the outside of the bacterial cell (Baumeister et al., 1989; Hovmöller et al., 1988; Koval \& Murray, 1986; Sleytr \& Messner, 1983, 1988; Smit, 1987). S-layers vary in chemical structure, with lattice spacings ranging from 2.8 to $35 \mathrm{~nm}$ and protein subunit molecular masses ranging from 13 to $255 \mathrm{kDa}$ (Koval \& Murray, 1986; Sleytr \& Messner, 1988; Smit, 1987). Once isolated from the cell, the protein subunits will reassemble into their native, sheetlike structures, under appropriate laboratory conditions. The subunits are held together in arrays by non-covalent bonding, including hydrogen bonds, hydrophobic interactions and ionic bonds (Sleytr \& Messner, 1983, 1988).

*Author for correspondence.

† Present address: Division of Materials Research, National Science Foundation, 1800 G. St N.W., Washington, D.C. 20550, USA.

Abbreviations: (D)DW, (distilled) deionized water; PS, polystyrene.
The proteins generally contain a large number of acidic and hydrophobic amino acids (Sleytr \& Messner, 1983), and are sometimes glycosylated (Sleytr \& Messner, 1988).

Because of their location at the interface between the cell and the surrounding medium, S-layers have a major influence on the interactions between the bacterium and its environment. They have a number of important functions, including protection from harmful molecules (e.g. degradative enzymes), predators (Sleytr \& Messner, 1988) or host immune systems (Dooley \& Trust, 1988; Dubreuil et al., 1988; Kay et al., 1981, 1984; Phipps et al., 1983). The presence of S-layers on cell surfaces can also result in an increase in cell hydrophobicity (Gruber \& Sleytr, 1991; Mozes \& Rouxhet, 1987; Sára et al., 1988), resulting in aggregation of the bacteria through hydrophobic interactions. Although it has been suggested that S-layers may act as bacterial adhesives (Koval, 1988; Sleytr \& Messner, 1983, 1988; Smit, 1987), the role of S-layer proteins in bacterial attachment to solid surfaces has not been determined.

In this study, we investigated the adsorption characteristics of two S-layer proteins and determined whether these paralleled the adhesion characteristics of the source 
bacteria. The adsorption and attachment substrata were a series of polystyrene (PS) surfaces that were treated for increasing periods with $\mathrm{H}_{2} \mathrm{SO}_{4}$, which provided surfaces that exhibited a progressive increase in substratum waterwettability. Thus, the surfaces had the same basic chemistry, yet differed in hydrophobicity, which could be expected to influence protein adsorption (Norde, 1986) and bacterial adhesion (Rosenberg \& Kjelleberg, 1986). The organisms were a Gram-negative Pseudomonas-like strain, designated EU2 (Austin et al., 1990) and the Gram-positive thermophile Bacillus coagulans (Pum et $a l ., 1989)$. The chemical structures of EU2 and $B$. coagulans S-layers are quite different. The S-layer of EU2 is a $55 \mathrm{kDa}$ protein, which assembles into a tetragonal array with a lattice constant of $13.2 \pm 0.1 \mathrm{~nm}$ and which can form three-dimensional crystals (Austin et al., 1990). Its pattern resembles those of Aeromonas salmonicida, Aeromonas hydrophila and Azotobacter vinelandii (Austin et al., 1990). B. coagulans, in contrast, has a $100 \mathrm{kDa}$ monomer S-layer protein which, when assembled, exhibits oblique symmetry (Pum et al., 1989).

\section{Methods}

Organisms and growth conditions. Strain EU2 and Bacillus coagulans E38-66 were kindly provided by R. G. E. Murray, University of Western Ontario, London, Ontario, Canada, and U. B. Sleytr, Zentrum für Ultrastrukturforschung, Universität für Bodenkultur, 1180 Vienna, Austria, respectively. EU2 was grown in a medium containing $0.3 \%$ yeast extract, $0.3 \%$ peptone and $0.02 \% \mathrm{MgSO}_{4}$ in deionized water (DW) (pH 7.3) for $46 \mathrm{~h}$ to stationary phase (ca $3 \times 10^{9}$ cells $\left.\mathrm{ml}^{-1}\right)\left(20^{\circ} \mathrm{C}\right.$ with shaking at 150 r.p.m.). B. coagulans was grown in nutrient broth, $\mathrm{pH} 6.8$ (Difco) for $20 \mathrm{~h}$ to stationary phase $\left(60^{\circ} \mathrm{C}\right.$ with shaking at 150 r.p.m.). Each organism was harvested by centrifugation ( $15 \mathrm{~min}, 4400 \mathrm{~g}$ ). Bacteria used in adhesion experiments were resuspended to the original culture volume in potassium phosphate buffer $\left(0.02 \mathrm{M}-\mathrm{KH}_{2} \mathrm{PO}_{4} ; 0.08 \mathrm{M}-\mathrm{K}_{2} \mathrm{HPO}_{4}\right)$, pH 7.6, or distilled-deionized water (DDW), $\mathrm{pH}$ 6.8. Phosphate buffer was included,

Table 1. Advancing $\left(\Theta_{A}\right)$ and receding $\left(\Theta_{R}\right)$ surface contact angles $\left({ }^{\circ}\right)$ of water on test substrata

\begin{tabular}{ccc}
\hline \hline $\begin{array}{c}\text { Treatment time* } \\
(\text { min })\end{array}$ & $\Theta_{\mathrm{A}}(\mathrm{SD})$ & $\Theta_{\mathrm{R}}(\mathrm{SD})$ \\
\hline 0 & $92(1)$ & $87(7)$ \\
$0 \cdot 25$ & $73(6)$ & $20(2)$ \\
0.50 & $75(6)$ & $11(5)$ \\
1 & $73(8)$ & $13(3)$ \\
2 & $69(7)$ & $8(3)$ \\
4 & $72(5)$ & $8(2)$ \\
8 & $68(6)$ & $7(2)$ \\
16 & $65(5)$ & $<5$ \\
32 & $63(6)$ & $<5$ \\
64 & $59(7)$ & $<5$ \\
128 & $57(6)$ & $<5$ \\
256 & $46(9)$ & $<5$ \\
TC $\dagger$ & $50(10)$ & $<5$ \\
\hline \hline
\end{tabular}

*Treated with $\mathrm{H}_{2} \mathrm{SO}_{4}$.

$\dagger$ Tissue-culture-treated PS. as this has been a routine medium for attachment assay in this laboratory, and its use allowed a comparison of these attachment data with those of other organisms. Some harvested bacteria were retained $\left(-80^{\circ} \mathrm{C}\right)$ for SDS-PAGE analysis of cell proteins.

Preparation and characterization of test surfaces. PS surfaces exhibiting a range of water-wettabilities were prepared to serve as attachment substrata. For most bacterial attachment experiments and all protein adsorption experiments, 96-well microtitre plates were used as substrata. However, as flat surfaces were required for contact angle $(\Theta)$ measurements, parallel sets of substrata were prepared from $3 \mathrm{~cm}$ Petri dishes (Sterilin). PS microtitre well clusters (Corning) were sulphonated by treatment with $300 \mu$ concentrated $\mathrm{H}_{2} \mathrm{SO}_{4}$ per well for 15 or $30 \mathrm{~s}, 1,2,4,8,16,32,64,128$ or $256 \mathrm{~min}$. Wells were then rinsed with filter-sterile DDW three times and allowed to air-dry. Petri dishes were treated in the same way, except $10 \mathrm{ml}^{\circ} \mathrm{H}_{2} \mathrm{SO}_{4}$ was used. Tissueculture-treated well clusters (Corning) were also used as test surfaces.

To quantify surface hydrophilicities, the advancing $\left(\Theta_{A}\right)$ and receding $\left(\Theta_{R}\right)$ contact angles of DDW on each surface type were measured using a calibrated goniometer eyepiece (PTI). $\Theta_{\mathrm{A}}$ measurements were made with $25 \mu$ drops, whereas $\Theta_{R}$ measurements were made by removing $2 \mu \mathrm{l}$ portions from the original $(25 \mu \mathrm{l})$ drop until no further change in contact angle was detected. At least 10 angles were measured for each surface. The $\Theta$ values for the test surfaces are given in Table 1 .

Isolation of $S$-layer proteins. For the isolation of EU2 S-layers, cultures were harvested by centrifugation $(3000 \mathrm{~g}, 20 \mathrm{~min})$ and washed twice in $100 \mathrm{ml}$ ice-cold $100 \mathrm{~mm}$-HEPES buffer ( $\mathrm{pH} 7 \cdot 5$ ). Bacteria were resuspended in $25 \mathrm{ml}$ buffer and disrupted by two passages through a French pressure cell at 1000 p.s.i. (6.89 MPa). Suspensions were centrifuged at $20000 \mathrm{~g}$ for $20 \mathrm{~min}$, and the pellet was treated as described by Austin et al. (1990), except that final dialysis was against $100 \mathrm{~mm}$-HEPES containing $7.5 \mathrm{mM}-\mathrm{CaCl}_{2}$ overnight at $4{ }^{\circ} \mathrm{C}$ with stirring, to remove the guanidine hydrochloride used to extract the S-layer. The precipitate, which formed after dialysis, represented the self-assembled $55 \mathrm{kDa}$ S-layer protein. This was confirmed by SDSPAGE and quantified by the BCA protein assay (Pierce). Precipitated material was further dialysed against DDW or phosphate buffer for subsequent adsorption experiments, so that the S-layer proteins would be in the same type of buffer used to suspend cells for attachment experiments (below).

B. coagulans S-layer was isolated by first washing $1 \mathrm{~g}$ (wet wt) of harvested bacteria $(7700 \mathrm{~g}, 20 \mathrm{~min}$ ) with $5 \mathrm{ml} 50 \mathrm{~mm}$-Tris $/ \mathrm{HCl}$ buffer (pH 7.2) and resuspending them in $5 \mathrm{ml}$ ice-cold Tris/HCl. Cells were disrupted by three passages through a French pressure cell at 1000 p.s.i., followed by centrifugation $(45000 \mathrm{~g}, 1 \mathrm{~h})$. The pellet was resuspended in ice-cold Tris $/ \mathrm{HCl}$ and washed three times. The washed envelope preparation was resuspended and mixed for $15 \mathrm{~min}$ in $50 \mathrm{~mm}$ Tris/ $\mathrm{HCl}(\mathrm{pH} 7 \cdot 2)$ containing $0.5 \%(\mathrm{w} / \mathrm{v})$ Triton $\mathrm{X}-100$ at $c a 25^{\circ} \mathrm{C}$ to solubilize any contaminating cytoplasmic membranes, followed by centrifugation at $45000 \mathrm{~g}(20 \mathrm{~min})$ and washing in ice-cold Tris/ $\mathrm{HCl}$ four times. Supernatants were saved for protein determinations to evaluate extraction efficiency. S-layer subunits were extracted by homogenizing the pellet in $10 \mathrm{vol} 5 \mathrm{M}$-guanidine hydrochloride and stirring gently overnight at $20^{\circ} \mathrm{C}$. After centrifugation $(45000 \mathrm{~g}$, $30 \mathrm{~min}$ ), the extraction procedure was repeated on the pellet. Extracts containing dissolved S-layers were combined and dialysed against frequent changes of $20 \mathrm{~mm}-\mathrm{KCl}$ containing $0.01 \%$ sodium azide at room temperature for up to $24 \mathrm{~h}$. Precipitated S-layer proteins were collected by centrifugation $(6000 \mathrm{~g}, 15 \mathrm{~min})$, and the presence and purity of S-layer protein was confirmed by SDS-PAGE. Considerable S-layer protein remained dissolved; thus, the supernatant was also retained. S-layer samples were further dialysed against DDW or phosphate buffer for adsorption experiments. Protein adsorption experiments were performed with solutions that contained both autoassembled and dissolved proteins, which were vortexed before use. 
Determination of isolated S-layer proteins. High molecular mass whole cell protein profiles were performed on cells to confirm the presence of the S-layer proteins. Pelleted cells were resuspended in filtered, sterile DDW to an overall protein concentration of ca $1.5 \mathrm{mg} \mathrm{ml}^{-1}$ (Pierce BCA protein assay) and treated with 4 vols SDSreducing buffer $[2 \%(\mathrm{w} / \mathrm{v}) \mathrm{SDS}, 25 \%(\mathrm{v} / \mathrm{v}) \mathrm{DDW}, 30 \%(\mathrm{v} / \mathrm{v})$ glycerol, $12.5 \%(\mathrm{v} / \mathrm{v}) 0.5 \mathrm{M}$-Tris $/ \mathrm{HCl}(\mathrm{pH} \mathrm{6.8)}, 10 \%$ (v/v) $\beta$-mercaptoethanol, $0.00125 \%$ bromophenol blue] at $95{ }^{\circ} \mathrm{C}$ for $5 \mathrm{~min}$. Gels were run on $9 \%$ SDS-PAGE using a discontinuous buffer system at $200 \mathrm{~V}$ (Laemmli, 1970) on a Mini-Protean II Duo Slab Cell (Bio-Rad). The molecular masses of S-layer proteins from both organisms were determined by calibration against standards using a Bio-Rad Densitometer/1-D Analyst II Software Program of SDS-PAGE gels, and were in agreement with published values (Austin et al., 1990; Pum et al., 1989).

Adhesion experiments of EU2 and B. coagulans. Cell suspensions were prepared in DDW or phosphate buffer and $250 \mu$ l aliquots were placed in microtitre wells, which served as attachment test surfaces. Bacteria were allowed to attach for $2 \mathrm{~h}$. EU2 and B. coagulans experiments were performed at 20 and $60^{\circ} \mathrm{C}$, respectively. After attachment, the remaining cell suspension was removed under light vacuum, and each surface was gently rinsed three times by adding $300 \mu \mathrm{l}$ of the respective diluent (DDW or phosphate buffer), followed by aspiration under light vacuum, to remove unattached bacteria. The biomass of attached bacteria was evaluated by measurement of cellular protein (Pierce BCA assay). The relationship between cell protein and cell numbers was determined from calibration curves prepared from dilution series of pure EU2 and $B$. coagulans cultures. All bacterial assays were done in triplicate and repeated at least twice.

During attachment experiments, it was possible that not all cells had S-layers. One or the other of these subpopulations might preferentially attach to surfaces. If so, cells remaining suspended after the attachment period would demonstrate a reduced tendency to attach. Thus, in some experiments, these remaining cells were collected and their attachment was determined. The attachment assay (above) was used, with the following exceptions. After $2 \mathrm{~h}$, cell suspensions were pipetted to new, but identically $\mathrm{H}_{2} \mathrm{SO}_{4}$-treated, test surfaces and allowed to adhere for $2 \mathrm{~h}$. Attachment was determined by binding of crystal violet dye to attached cells (Fletcher, 1976).

After the first $2 \mathrm{~h}$ attachment period, both attached cells and those remaining in suspension were analysed by SDS-PAGE to ensure that both subpopulations had S-layers. Attached, rinsed cells were treated while on the substratum with $100 \mu \mathrm{l}$ of SDS-reducing buffer for $2 \mathrm{~h}$ at $37^{\circ} \mathrm{C}$. Cell suspensions $(250 \mu \mathrm{l})$ were centrifuged in Eppendorf centrifuge tubes for $5 \mathrm{~min}$ at 12000 r.p.m. using an Eppendorf Centrifuge 5415 and the pellets treated with $100 \mu$ l SDS-reducing buffer. Both samples were then heated at $95^{\circ} \mathrm{C}$ for $5 \mathrm{~min}$, run on $9 \%$ discontinuous acrylamide gels, and stained with Coomassie Brilliant Blue (EM Science). The presence of the S-layers was confirmed by the presence of protein bands of $c a 55 \mathrm{kDa}$ (EU2) or $100 \mathrm{kDa}(B$. coagulans).

EU2 and B. coagulans S-layer protein adsorption and measurement. The procedure for measuring adsorption of isolated $S$-layer protein was similar to that used to assess bacterial attachment (above). Adsorbed protein was estimated using the Pierce BCA assay $\left(0-60 \mu \mathrm{g} \mathrm{ml}^{-1}\right.$ range), using standard curves prepared from bovine serum albumin (BSA) in DDW or phosphate buffer. S-layer adsorption to the surfaces was confirmed by adding SDS-reducing buffer to rinsed wells, followed by SDS-PAGE of extracted protein. Stock BSA (Sigma; Fraction V powder; cat. no. A 6793) solutions were made up in filter-sterile DDW to a concentration of $77.84 \mu \mathrm{g} \mathrm{ml}^{-1}$. Adsorption assays were devised and tested using BSA at $25^{\circ} \mathrm{C}$ in DDW. All adsorption experiments included at least three replicates and were repeated at least twice, except for B. coagulans S-layer in DDW which was done once with eight replicates.

\section{Results}

Adhesion of EU2 organisms and adsorption of S-layer protein to test surfaces

When EU2 cells were resuspended in DDW, the numbers of attached cells decreased with an increase in surface hydrophobicity (Fig. 1a). The relationship between numbers of attached cells and $\Theta_{\mathrm{A}}$ was linear $\left(r^{2}=0.63\right)$. Negligible $\left(<0.5 \mu \mathrm{g} \mathrm{cm}^{2}\right)$ EU2 S-layer protein adsorbed to any of the test surfaces (Fig. $1 b$ ) when the protein was suspended in DDW. The data for untreated PS and tissue-culture-treated PS followed these general trends (data not shown). However, in these experiments, and those described below, they were not included in regression analyses, as they tended to be inconsistent, presumably due to unknown variations in surface properties (e.g. adsorbed material) that were introduced during manufacture or packing and that could be removed or obscured by $\mathrm{H}_{2} \mathrm{SO}_{4}$ treatment.

EU2 cells resuspended in phosphate buffer attached in high numbers to hydrophobic surfaces, whereas only few attached to hydrophilic surfaces (Fig. $2 a)\left(r^{2}=0 \cdot 79\right)$.
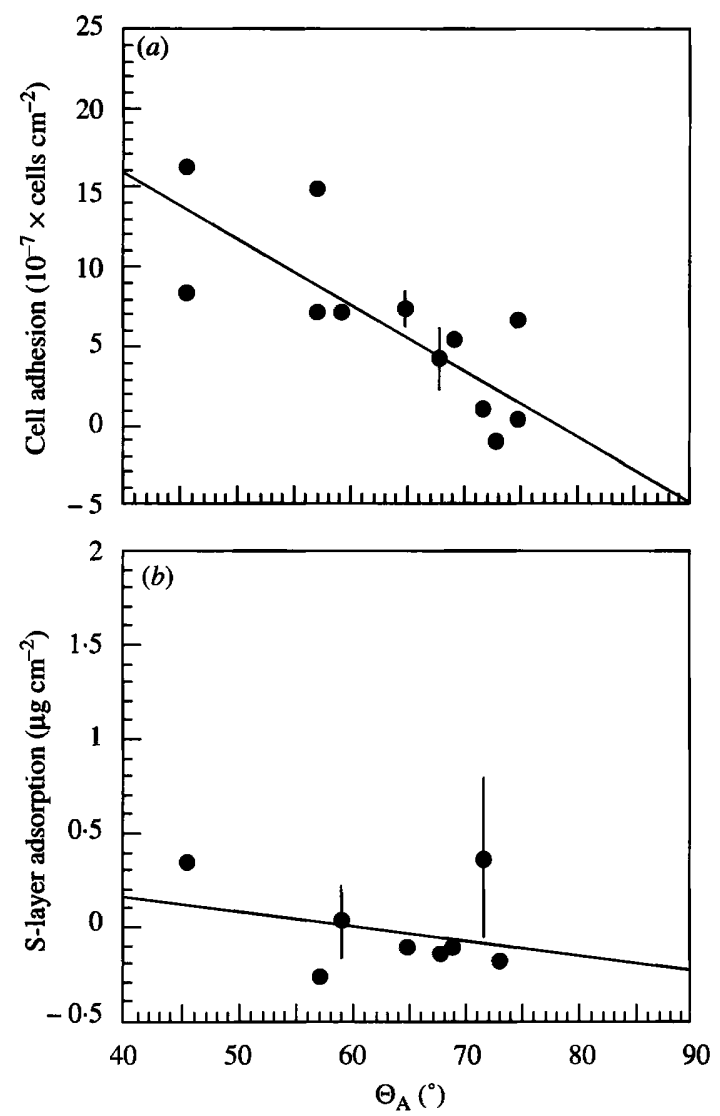

Fig. 1. Relationship between $\Theta_{\mathrm{A}}$ and (a) adhesion of EU2 cells $\left(r^{2}=0.63\right)$. (b) Negligible adsorption of the $55 \mathrm{kDa}$ S-layer protein to microtitre wells at $20^{\circ} \mathrm{C}\left(r^{2}=0 \cdot 63\right)$. Cells and proteins were suspended in DDW. Standard deviations are smaller than symbols, unless otherwise indicated; results are means from two experiments. 

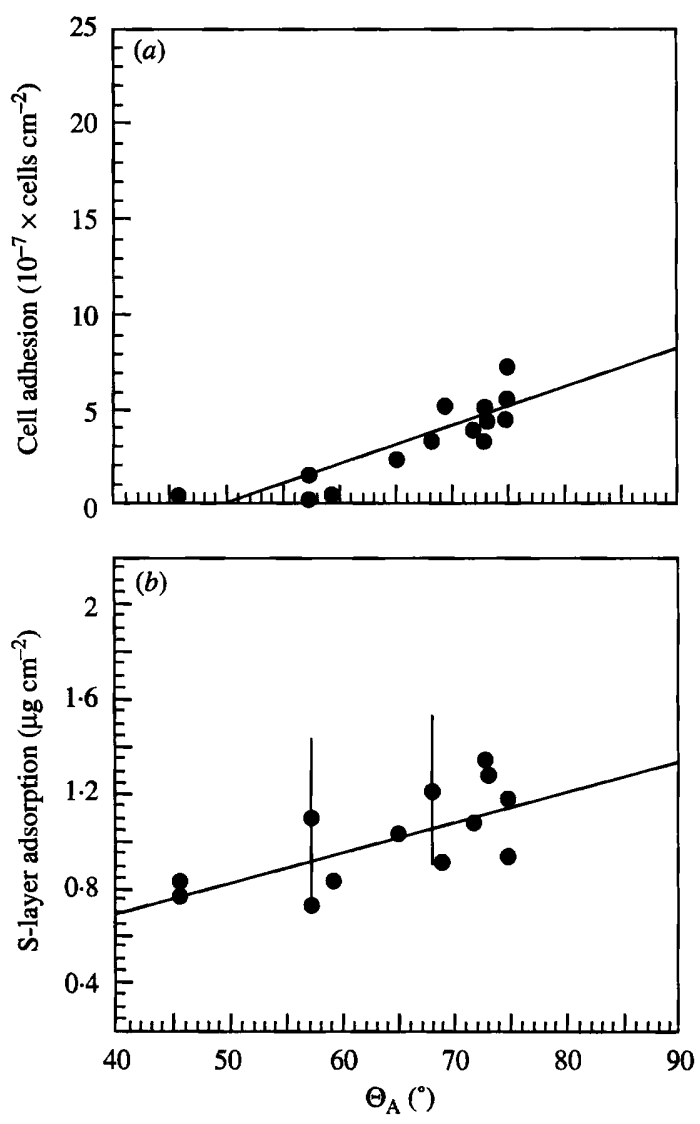

Fig. 2. Relationship between $\Theta_{\mathrm{A}}$ and (a) adhesion of EU2 cells $\left(r^{2}=0.79\right)$ or $(b)$ the $55 \mathrm{kDa}$ S-layer protein $\left(r^{2}=0.46\right)$ to microtitre wells at $20^{\circ} \mathrm{C}$. Cells and proteins were suspended in phosphate buffer. Standard deviations are smaller than symbols, unless otherwise indicated; results are means from two experiments.

There was appreciable adsorption of EU2 S-layer protein in phosphate buffer (Fig. $2 b)\left(r^{2}=0.46\right)$, compared with DDW (Fig. 1b). Adsorption increased with increasing substratum hydrophobicity, which paralleled the relationship obtained for cell attachment.

\section{Adhesion of B. coagulans and adsorption of S-layer protein to test surfaces}

With B. coagulans resuspended in DDW, the numbers of attached cells tended to decrease with increasing surface hydrophobicity (Fig. $3 a)\left(r^{2}=0 \cdot 35\right.$ ), and there was considerable variation in attachment numbers on replicate surfaces. No cells attached to tissue-culture-treated surfaces. Adsorption of $B$. coagulans $\mathbf{S}$-layer protein in DDW also decreased with increase in substratum hydrophobicity (Fig. $3 b)\left(r^{2}=0 \cdot 72\right)$. This pattern existed for proteins adsorbing at $60^{\circ} \mathrm{C}$ (Fig. $3 b$ ) and at $25^{\circ} \mathrm{C}$ (Fig. 4a) $\left(r^{2}=0.84\right)$. However, the amount of S-layer protein adsorbed was considerably greater at the higher temperature. The relationship between adsorption of BSA and substratum hydrophobicity was similar to that
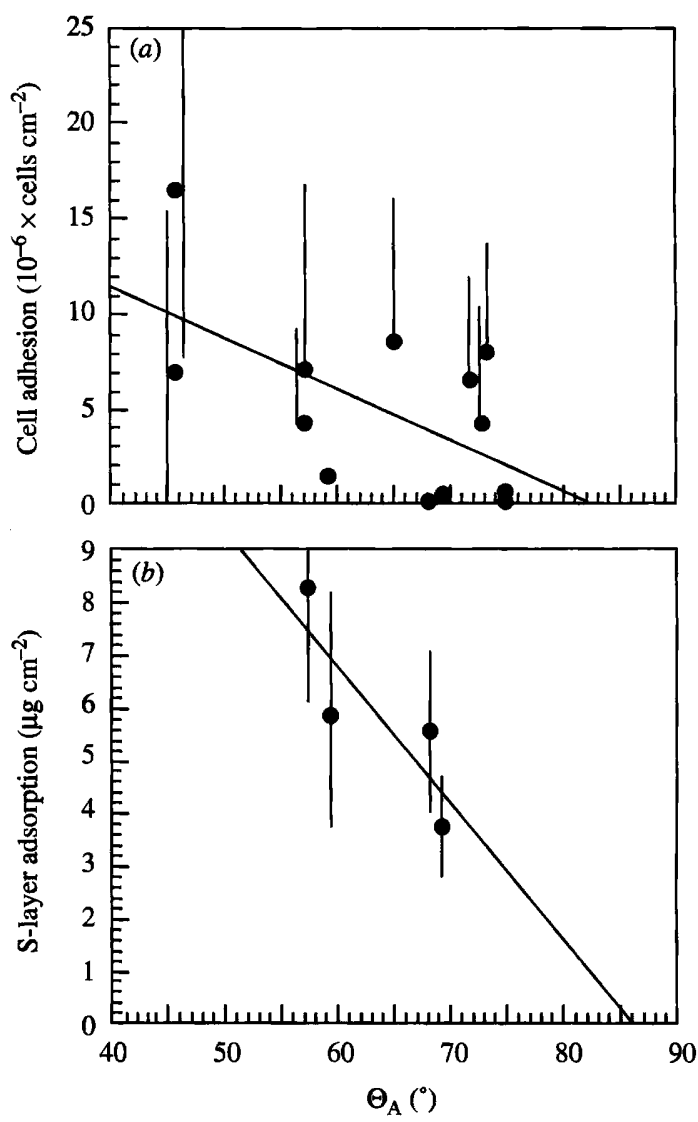

Fig. 3. Relationship between $\Theta_{\mathrm{A}}$ and $(a)$ adhesion of $B$. coagulans cells $\left(r^{2}=0.35\right)$ or $(b)$ the $100 \mathrm{kDa}$ S-layer protein $\left(r^{2}=0.72\right)$ to microtitre wells at $60^{\circ} \mathrm{C}$. Cells and proteins were suspended in DDW. Standard deviations are smaller than symbols, unless otherwise indicated; results are means from two experiments.

of B. coagulans S-layer protein in DDW at $25^{\circ} \mathrm{C}$ (Fig. $4 b$ ).

When $B$. coagulans was resuspended in phosphate buffer, there was no relationship between the number of attached cells and substratum hydrophobicity (Fig. $5 a$ ) $\left(r^{2}=0 \cdot 16\right)$, and attached cell numbers were relatively low. However, there was an inverse correlation between S-layer protein adsorption and substratum hydrophobicity $\left(r^{2}=0.52\right)$. This was similar to the relationship obtained in DDW, although the amount of protein adsorbed was higher in the latter.

\section{Tests for population heterogeneity}

In some experiments, EU2 or B. coagulans cells which remained in suspension after the first $2 \mathrm{~h}$ attachment period were collected and exposed to a fresh series of substrata for a further $2 \mathrm{~h}$ attachment period. Cells that attached during this second period demonstrated the same relationship between attached cell numbers and substratum contact angle that was observed with bacteria during the first attachment period (data not shown). 

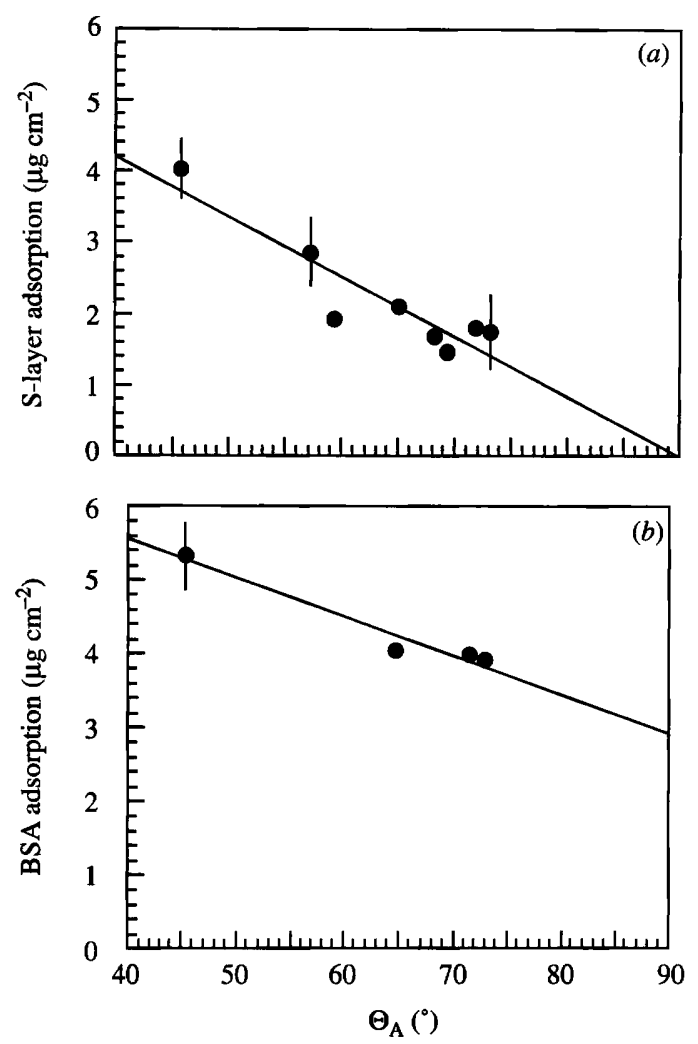

Fig. 4. Relationship between $\Theta_{\mathrm{A}}$ and (a) adhesion of $B$. coagulans S-layer protein $\left(r^{2}=0.84\right)$ or $(b)$ BSA $\left(r^{2}=0.96\right)$ at $20^{\circ} \mathrm{C}$. Standard deviations are smaller than symbols, unless otherwise indicated; results are means from two experiments (a) or data from one experiment $(b)$.

Also, SDS-PAGE analysis of both cell samples (adhered and non-adhered cells after $2 \mathrm{~h}$ ) demonstrated the presence of the S-layer protein in all subpopulations of bacteria (data not shown).

\section{Discussion}

There were considerable differences in both S-layer adsorption and bacterial adhesion to the various treated substrata. The PS surfaces had been treated with $\mathrm{H}_{2} \mathrm{SO}_{4}$, which introduces groups capable of polar interactions (Birdi, 1981) and of binding cations (Martin \& Rubin, 1974). Increasing treatment time resulted in an increase in capacity for polar interactions, indicated by changes in $\Theta_{\mathrm{A}}$ and $\Theta_{\mathrm{R}}$.

We hypothesized that, since the S-layer protein comprises the outermost layer of both EU2 and $B$. coagulans, it should function as the adhesive during cell attachment and, thus, the relationship between S-layer protein adsorption and substratum water contact angle would be the same as that between bacterial attachment and substratum contact angle. In two out of four cases, S-layer adsorption paralleled cell attachment. In one case, the number of attached EU2 cells and the amount of S-layer adsorption in phosphate buffer both increased
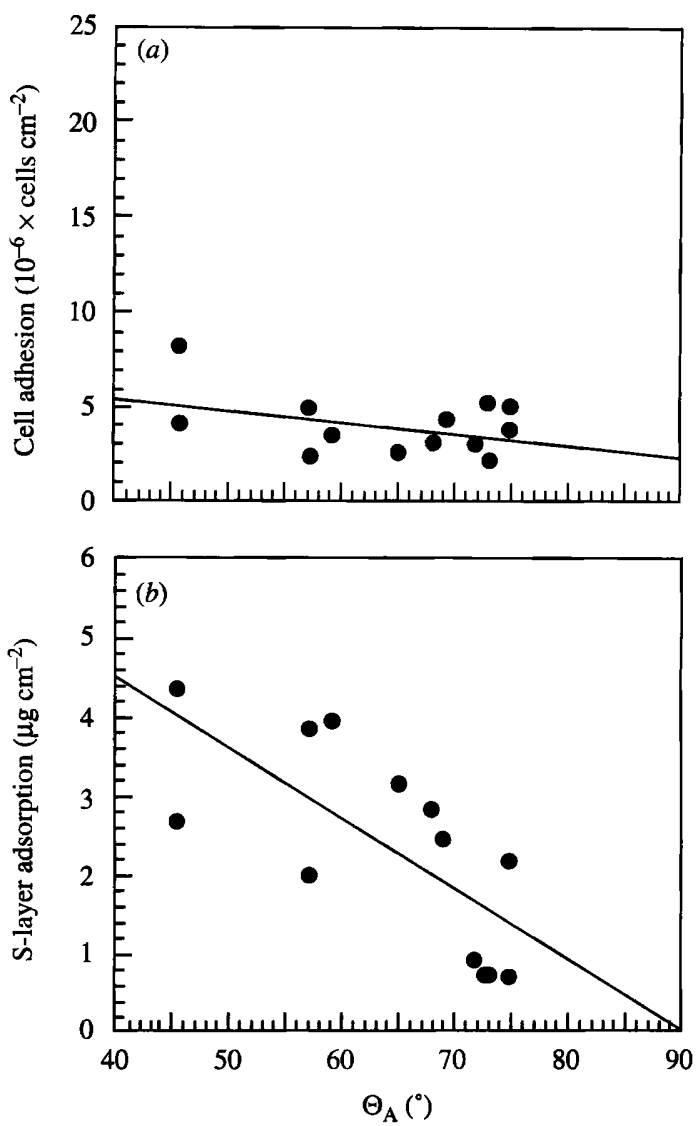

Fig. 5. Relationship between $\Theta_{\mathrm{A}}$ and $(a)$ adhesion of $B$. coagulans cells $\left(r^{2}=0.16\right)$ or $(b)$ the $100 \mathrm{kDa}$ S-layer protein $\left(r^{2}=0.52\right)$ to microtitre wells at $60^{\circ} \mathrm{C}$. Cells and proteins were suspended in phosphate buffer. Standard deviations are smaller than symbols, unless otherwise indicated; results are means from two experiments.

with increasing substratum hydrophobicity. In the second case, the number of attached $B$. coagulans cells and S-layer adsorption in DDW both decreased with increasing substratum hydrophobicity, although there was considerable variation in numbers of attached cells. As noted above, meaningful correlations for the other two cases were not observed. Thus, there was not a simple relationship between cell adhesion and S-layer protein adsorption. Moreover, the two organisms were quite different, with respect to both attachment and adsorption of their S-layer proteins, illustrating significant differences in the surface chemistries of the two organisms (Austin et al., 1990; Pum et al., 1989).

A possible explanation for the disparities between Slayer adsorption and bacterial adhesion is that S-layer proteins in solution would be free to adsorb to the substrata by both inner or outer faces, as well as by their 'edges'. In contrast, bacterial cells could adhere only by adsorption of the outer faces of S-layers. Also, adsorption of an S-layer subunit free in solution would be thermodynamically dissimilar from adsorption of an 
assembled S-layer or one intact on a cell. Adsorption by inner faces of S-layers could be considerably different from that of outer faces, because of the asymmetry of the charge distribution characteristic of numerous S-layer proteins (Hovmöller et al., 1988), including those of the thermophilic Bacillaceae (Sára \& Sleytr, 1987). Inner faces are generally charged, allowing interaction with the cell envelope, whereas the outer faces are neutral and hydrophobic. Little is known about the chemical structure of EU2 S-layer protein, but it probably has the anisotopic structure of many S-layers. Thus, with EU2 cells in DDW, the negligible protein adsorbed may have been due to solvation of the protein in DDW via the negatively charged inner faces.

With B. coagulans S-layer protein, there are carboxyl groups on both inner and outer faces, but only the inner face has a net negative charge (Pum et al., 1989). The outer faces are capable of hydrophobic interactions, and tend to adhere to one another when in solution. Even though the inner faces are negatively charged, and are capable of electrostatic interactions or salt bridging, the S-layer protein binds to positively charged, polylysinecoated surfaces by the outer faces. Apparently, on polylysine substrata, the tendency of these proteins to interact via hydrophobic interactions exceeds that for electrostatic interactions at the inner faces (Pum et al., 1989). In these experiments, the orientations of S-layers adsorbed on the different surfaces are unknown, but it may be possible to establish these by treatment of adsorbed S-layers with polycationized ferritin (PCF), followed by electron microscopy. PCF would bind to the negatively charged inner faces of the $B$. coagulans S-layer, but not to the outer faces (Pum et al., 1989). It is difficult to explain the results obtained with $B$. coagulans in phosphate buffer on the basis of our knowledge of the S-layer protein structure. However, S-layer proteins from both Gram-negative and Gram-positive bacteria have been found to reassemble on suitability charged surfaces (Sleytr \& Messner, 1988). Possibly the increase in adsorption that occurred with increase in substratum hydrophilicity was due to polar interactions involving the protein inner faces.

A second, though less likely, explanation for the observed inconsistencies between bacterial attachment and S-layer adsorption is that the adsorption characteristics of the S-layer proteins were masked or altered by the presence of other macromolecules at the bacterial surface. Freeze-etch and negative-staining combined with transmission electron microscopy have provided no evidence of molecular layers exterior to these S-layers (Austin et al., 1990; Pum et al., 1989), but such observations do not preclude the possibility of additional minor components that could influence bacterial attachment.
A third possible reason for the difference between bacterial attachment and S-layer adsorption is that the bacteria that attached during the assay did not in fact have S-layers. As described above, we tested for this possibility by repeating attachment experiments with the bacteria that remained suspended after $2 \mathrm{~h}$ exposure to substrata and found that their behaviour was the same as that of the original population. Similarly, we assayed, by SDS-PAGE, for the presence of S-layers in the original population, the attached population, and those bacteria that did not attach, and found S-layers in all samples.

Frequently, attachment and protein adsorption results were different in DDW and phosphate buffer. This was particularly pronounced with EU2, as opposite relationships between cell attachment and substratum hydrophobicity were obtained in the two solutions, and hydrophobic interactions appeared to be increased in phosphate buffer. Also, adsorption of S-layer protein was considerably increased in phosphate buffer, particularly to hydrophobic surfaces. With $B$. coagulans, relationships between protein adsorption and substratum hydrophobicity were similar in DDW and phosphate buffer, except there was less variation among replicates in phosphate buffer. Also, there was some indication that attachment to hydrophobic surfaces increased in phosphate buffer. These observations can be explained by an increase in hydrophobic interactions favoured by an increase in electrolytes. This is analogous to the 'salting out' of proteins by addition of ions. The basis for this effect is generally thought to be competition between the protein and ions for water of hydration. At a particular ionic concentration, which depends on the protein and ion, the proteins are unable to compete and are excluded from solution (Deutscher, 1990). Potassium phosphate, the basis of the buffer used in these experiments, is commonly used to salt out proteins to isolate them and would be expected to enhance hydrophobic interactions (Deutscher, 1990).

The relationship between $B$. coagulans S-layer adsorption and substratum hydrophobicity was similar to that obtained with BSA. We originally used BSA for development of the protein adsorption micro-assay, but then observed that its adsorption behaviour was similar to that of the S-layer. Although BSA is structurally quite different from $B$. coagulans S-layer, the proteins are similar in the respect that both have portions that bear a net negative charge or that enter into hydrophobic interactions. Additional chemical information on the chemistry of EU2 S-layer protein is required before its different adsorption behaviour can be interpreted.

In summary, some of these results indicate that Slayers may play a role in bacterial adhesion to solid surfaces. However, the adhesiveness of S-layers clearly depends upon their specific chemical structures and on 
environmental conditions, such as electrolyte concentration or temperature. Because of the lack of a strong and consistent correlation between S-layer adsorption and bacterial attachment observed in these studies, further evidence is required to determine the possible role of S-layers in bacterial adhesion.

This work was supported by EPA Cooperative Agreement Award CR-814875-01-0 to H.H.W. We are grateful to R. G. E. Murray and U. B. Sleytr for supplying the organisms, to U. B. Sleytr and J. W. Austin for advice on S-layer isolation, to R. Zimmerman for technical help, and to G. Vasta for helpful discussions. Contribution no. 184 from the Center of Marine Biotechnology.

\section{References}

Austin, J. W., Stewart, M. \& Murray, R. G. E. (1990). Structural and chemical characterization of the $\mathrm{S}$ layer of a Pseudomonas-like bacterium. Journal of Bacteriology 172, 808-817.

Baumeister, W., Wildhaber, I. \& PhIPps, B. M. (1989). Principles of organization in eubacterial and archaebacterial proteins. Canadian Journal of Microbiology 35, 215-227.

BIRDI, K. S. (1981). The role of surface forces on the cell adhesion on solids. In Tooth Surface Interactions and Preventive Dentistry, pp. 207-217. Edited by G. Rolla, T. Sonju \& G. Embury, London: IRL Press.

Deutscher, M. P. (1990). Guide to Protein Purification. San Diego: Academic Press.

DoOLEY, J. S. G. \& TRUST, T. J. (1988). Surface protein composition of Aeromonas hydrophila strains virulent for fish: identification of a surface array protein. Journal of Bacteriology 170, 499-506.

Dubreuil, J. D., Logan, S. M., Cubbage, S., Eidhim, D. N., McCubbin, W. S., Ferris, F. G., Day, C. M., Beveridge, T. J. \& TRUST, T. J. (1988). Structural and biochemical analysis of a surface array protein of Campylobacter fetus. Journal of Bacteriology 170, 4165-4173.

FLETCHER, M. (1976). The effects of proteins on bacterial attachment to polystyrene. Journal of General Microbiology 94, 400-404.

GRUBER, K. \& SLEYTR, U. B. (1991). Influence of an S-layer on surface properties of Bacillus stearothermophilus. Archives of Microbiology 156, 181-185.

Hovmöller, S., SJOGREN, A. \& WANG, D. N. (1988). The structure of crystalline bacterial surface layers. Progress in Biophysics and Molecular Biology 51, 131-163.

Kay, W. W., Buckley, J. T., Ishiguro, E. E., Phipps, B. M., Monette, J. P. L. \& Trust, T. J. (1981). Purification and disposition of a surface protein associated with virulence of Aeromonas salmonicida. Journal of Bacteriology 147, 1077-1084.

Kay, W. W., Phipps, B. M., Ishiguro, E. E., Olafson, R. W. \& Trust, T. J. (1984). Surface layer virulence A-proteins from Aeromonas salmonicida strains. Canadian Journal of Biochemistry and Cell Biology 62, 1064-1071.

Koval, S. F. (1988). Paracrystalline protein surface arrays on bacteria. Canadian Journal of Microbiology 34, 407-414.

Koval, S. F. \& MurRay, R. G. E. (1986). The superficial protein arrays on bacteria. Microbiological Sciences 3, 357-361.

LAEMMLI, U. K. (1970). Cleavage of structural proteins during the assembly of the head of bacteriophage T4. Nature, London 227, 680-685.

Martin, G. R. \& Rubin, H. (1974). Effects of cell adhesion to the substratum on the growth of chick embryo fibroblasts. Experimental Cell Research 85, 319-333.

Mozes, N. \& Rouxhet, P. G. (1987). Methods for measuring hydrophobicity of microorganisms. Journal of Microbiological Methods 6, 99-112.

NORDE, W. (1986). Adsorption of proteins from solution at the solid-liquid interface. Advances in Colloid Interface Science 25, 267-340.

Phipps, B. M., Trust, T. J., Ishiguro, E. E. \& Kay, W. W. (1983). Purification and characterization of the cell surface virulent Aprotein from Aeromonas salmonicida. Biochemistry 22, 2934-2939.

PuM, D., SÁrA, M. \& SleYTR, U. B. (1989). Structure, surface charge and self-assembly of the S-layer lattice from Bacillus coagulans E3366. Journal of Bacteriology 171, 5296-5303.

RosenberG, M. \& KJELLEBERG, S. (1986). Hydrophobic interactions: role in bacterial adhesion. Advances in Microbiol Ecology 9, 353-393.

SÁRA, M. \& SLEYTR, U. B. (1987). Charge distribution on the S layer of Bacillus stearothermophilus NRS1536/3c and importance of charged groups for morphogenesis and function. Journal of Bacteriology 169, 2804-2809.

SÁRA, M., KAlSNER, I. \& Sleytr, U. B. (1988). Surface properties from the S-layer of Clostridium thermosaccharolyticum D120-70 and Clostridium thermohydrosulfuricum L111-69. Archives of Microbiology 149, 527-533.

Sleytr, U. B. \& Messner, P. (1983). Crystalline surface layers on bacteria. Annual Review of Microbiology 37, 311-339.

SLEYTR, U. B. \& Messner, P. (1988). Crystalline surface layers in prokaryotes. Journal of Bacteriology 170, 2891-2897.

SMIT, J. (1987). Protein surface layers of bacteria. In Bacterial Outer Membranes as Model Systems, pp. 343-376. Edited by M. Inouye. New York: John Wiley. 